\title{
11 \\ Unfettering the Mind: Imagination, Creative Writing and the Art of the Historian
}

Tessa Morris-Suzuki

\section{A cry in the night}

It was perhaps an hour later, or perhaps the following night, that I was once more wakened by the stammer of a tugboat's engine, and now I seemed to hear beneath it a troubled, human cry. This time it was futile to hold the bedclothes against my ears; I could not escape a sense of responsibility (Hutchinson 1969: 9).

Those are the opening words of a novel that has lurked in the depths of my consciousness ever since I first read it as an undergraduate around the start of the 1970s. In some quiet way, it has shaped my understanding of history, and now as I approach the end of my university career, still struggling with questions of historical justice and responsibility, I have found myself returning to it and rereading it, each time discovering something new in its pages. It provides, I think, a good starting point for some reflections about works that bring together the art of creative writing and the craft of the historian.

The novel, Johanna at Daybreak, was written by British author Ray Coryton Hutchinson (1907-1975) and published in 1969. Today it is little known and rarely read. Hutchinson's early work earned much praise, 
and his posthumously published novel Rising was listed for the Booker Prize, but his books somehow fell out of fashion and into an obscurity that is only occasionally lifted as, here and there, a contemporary reader rediscovers his writings (Green 1985). In a recent blog, the novelist Peter Hobbs writes:

I've always found it strange how the reputations of so many writers have very little to do with the quality of their work. It can take many decades before there's a levelling out or reappraisal. In the short and medium terms weak writers may be lauded, and great writers forgotten. R.C. Hutchinson seems to have been in the latter category—he's almost unknown amongst writers of my generation or younger ... Great writing is often far from where the publishing noise is, and where the headlines are, and sometimes it can get lost for a while. But it tends to find its way, at least to people who care for it. ${ }^{1}$

The obscurity is understandable. The 1950s and 1960s were decades of social realism in British literature, when the literary prize lists were dominated by the Kingsley Amises, Angus Wilsons and Margaret Drabbles of the world. But through these decades, R.C. Hutchinson went on doing as he had always done: writing novels on vast, sprawling Dostoyevskian themes of life and death, evil and remorse, faith, redemption and revolution. Many of his works are set in places far from the English Home Counties where he lived. His stories unfold in the foggy backstreets of wartime Germany, the steppes of revolutionary Russia and the guerrilla hideouts of Latin America. Hutchinson reaches boldly for the great metaphysical questions of life, and sometimes falls short-slipping into passages of prose that are overheated, overlong or overburdened with religious imagery. But when his work succeeds, it succeeds magnificently. At its best, his writing has that power peculiar to the creative arts. It can change the way you see the world.

In the opening pages of Johanna at Daybreak, Hutchinson drags his readers out of their comfortable chairs and transports them, without explanation or apology, into a bleak and dreamlike place that proves to be a refuge for displaced persons set in the chaos of the Netherlands just after the end

1 'Peter Hobbs hails R.C. Hutchinson and his "brave, compassionate, moral" novel "A Child Possessed"'. Faber and Faber, 22 April 2013. Online: faberfindsblog.co.uk/peter-hobbs-hails-r-chutchinson-and-his-brave-compassionate-moral-novel-a-child-possessed/ (accessed 17 November 2016). 
of World War II. More disconcertingly still, his first-person narrative takes the reader inside the mind of Johanna Schechter, a German woman who has lost her memory.

Over the past two decades or so, questions of memory, commemoration, trauma and historical responsibility have become staples of historical research and the subjects of countless books, articles and conferences. Whole research institutes are devoted to these themes. But when Johanna at Daybreak was published, few historians had yet ventured into the labyrinthine realms of memory. Hutchinson is adventurous in his choice of topics; and his novels, like much good creative writing, reach into dimensions of history that often escape the more sober and constricted prose of the academic historian.

For Johanna, memory loss is a refuge, but an insecure one. The past keeps threatening to seep through cracks in her amnesia, just as in Michael Hanneke's haunting film Caché (Hidden) (2005) it seeps up through the cracks in the complacent middle-class world of contemporary Paris. For Johanna, a certain name or encounter has the troubling power to light a spark in her mind:

as if I had once seen it on some signpost or in a newspaper headline, but there was ... no reason to pursue it on my own account. I had learnt the folly of such researches ... The past, for me, was such a region as precocious children invent to scare each other, a cavernous darkness peopled with menacing shadows, and I did not need to distress and alarm myself by turning in that direction: the present was enough for me to cope with (Hutchinson 1969: 19).

So Hutchinson invites his readers to see the world through the eyes, not of the victims of evil, but of someone who, at an obscure subconscious level, is aware that she is a wrongdoer, but has found psychological defenses to seal herself off from confronting that knowledge. The daily routines and dramas of the displaced persons' hostel absorb all her energy and all her waking consciousness. Only in her dreams does she seem to hear the 'troubled human cry', and know for a fleeting moment that she cannot 'escape a sense of responsibility'. 


\section{Escaping the despotism of the past}

The theme of historical responsibility is a universal one, of which Johanna's story is just an extreme illustration. For most readers too, 'the present is enough for us to cope with', a place whose absorbing routines allow us to create a comforting amnesia, even if in a less drastic form than Johanna Schechter's loss of memory. But the novel resists simple universalisms and generalisations, and allows room to evoke the multiplicities of memory and forgetting. In Johanna at Daybreak, the counterpoint to the main character's amnesia is the mental confusion of the tragic but somehow majestic Debora Stahl, a Jewish woman whose refuge lies, not in forgetting the past, but in forgetting the present: Madame Stahl, despite all the evidence of her shabby and chaotic surroundings, believes herself to be living still in the glittering social world of her 1920s youth. It is the arrival of Debora Stahl and her husband Walther in the displaced persons' hostel that makes the first decisive breach in the walls of Johanna's amnesia, starting a process that will ultimately force her to confront the 'cavernous darkness' of history.

Johanna's final nemesis, though, lies in encounters with her own family, among them her brother-in-law Albrecht, a fellow German whose life has been torn apart by the consequences of Nazism, and who is unrelenting in his determination to remember:

'Yes,' [Albrecht] continued, 'I tried to forget all that. But now I don't want to forget it. In a way I was responsible myself for what happened, because we all were-we stood and watched them making a world where things like that could happen. And we can't say, "Well, it's time to put all that behind us"- that would just be a cowardly evasion.' His voice had remained cool and colourless, but now, as a dry bay leaf under a magnifying glass will suddenly burst into flame, it yielded to the passion that he had been suppressing: with a fury that pierced my ears and brain like a heated wire he said, 'Those things are not to be forgotten! I tell you, I will not let anyone forget them' (Hutchinson 1969: 166, emphasis in original).

'I will not let anyone forget': that, surely, might be a motto for the historian. But the reader, confronting Albrecht's remorseless righteousness, can also see that work of memory is at times a kind of violence. The novel invites us to consider the nature of and need for that violence. It poses questions, 
not only to those who escape into amnesia, but also to those who insist on remembering. The novel, unlike the academic text, is not expected to offer tightly argued conclusions; the questions do not have simple answers.

Most centrally of all, Johanna at Daybreak takes up a question with which scholarly history still struggles: the issue of forgiveness, or, more precisely the problem of the withholding of forgiveness. Recent debates about historical responsibility, apology and reconciliation have encouraged new waves of writing on the ethics and politics of forgiveness. Jacques Derrida, in the late 1990s, published a series of challenging philosophical essays on the subject, in which he argued that forgiveness in the true sense of the word can only be absolute, unconditional and independent of the remorse of the offender. Forgiveness, in Derrida's terms, is an ultimate act of selfdetermination by the wronged victim, but at the same time an act that becomes virtually impossible: 'forgiveness forgives only the unforgivable' (Derrida 2001: 32; see also McGonegal 2009: 41-42).

But R.C. Hutchinson in the 1960s was more concerned with the question of unforgiveness. What happens when our apologies or sense of responsibility for the past are insufficient to melt the hearts of those we have wronged? What happens if the past is simply unforgivable?

In my research on issues of historical conflict and reconciliation in Northeast Asia, I have become increasingly aware of the power and perils of the longing for forgiveness. The wrongs of the past create injustices that persist into the present. This places burdens of responsibility even on those who were not personally responsible for the original sin, but who have failed to right enduring injustices that flow from this sin. Which of us can endure the terrible moral absolute which R.C. Hutchinson lays out before us: a world in which there are only 'two sorts of people-one lot who goes through hell, and the other lot that makes them, or else just stands back and does nothing' (Hutchinson 1969: 305)? In people who inherit a responsibility-laden past or present, the hunger for absolution can become intense and laden with emotion. To be forgiven by those who 'go through hell' is to have a burden lifted from our shoulders, our self-esteem restored, our hearts liberated. Receiving heartfelt forgiveness is calming and deeply comforting.

But the longing to be forgiven can be a dangerous emotion. It may impel those with uneasy consciences to force their awkward words of apology onto others who lack the time or energy to take on the demanding task 
of forgiving. Worse still, people who apologise for the past may, all too easily, assume that their apology is one side of a simple reciprocal exchange: that the automatic result of any apology, however thin or light, will be an instant offer of forgiveness. This vision of the apology-forgiveness exchange as a reciprocal—almost a commercial—barter encourages the apologiser to feel cheated when instant forgiveness fails to materialise: 'I said sorry. Why are they still complaining?' The sense of guilt, or at least responsibility, is then radically but all too easily inverted into that strange phenomenon: the perpetrator's sense of victimhood.

The unfulfilled longing for forgiveness can lead to a renewed rejection of memory and of the past. When Johanna Schechter is confronted by the walls of unforgiveness, her overwhelming temptation is to retreat again into amnesia:

Detachment: that was an operation which the mind could manage with its own resources. The past, I thought, need not command us. The burdens which arrived each day-the stress of fending for oneself, the pain of watching in the glass a creature who will presently grow old and uselessthese should suffice to fill one's mental horizon: only perversity would make one look backward to revive old causes of distress. Yes, I needed to be vigilant; but now it occurred to me that I was expert in such vigilance already - I had only to re-employ the faculty of suppression which I had wantonly discarded (Hutchinson 1969: 306).

But the cost of amnesia is isolation, a retreat from human society, for fear that any encounter with others may once again stir the agonising pangs of memory. In the final pages of Johanna at Daybreak, R.C. Hutchinson evokes the story of the seventeenth-century Italian convict Jacopo Frugoni, who escaped from prison and fled eastward across the Mediterranean in a stolen boat, only to find that escape brought a more frightening form of captivity. In every port where he stopped, he was seized by the terrifying certainty that he had seen familiar faces in the crowd, and was about to be recognised. The terror only subsided when he set sail alone again on his boat; but then he would be assailed by a new fear-the fear of unending solitude, to which he now seemed condemned. Those who deny the past, Hutchinson suggests, are condemning themselves precisely to that endless solitude. True apology acknowledges the right of the victim to withhold forgiveness. The only escape from solitude is to face the past and the present in a world where one remains unforgiven. 
But this is a novel, not a philosophical text. Academic writing abstracts. It draws the fine threads of specific themes out of the tangled fabric of everyday life, and holds them up to the light. The novel, on the contrary, finds its life in the midst of the tangle. Derrida's reflections on the ethics of forgiveness are searching and profound, but utterly abstracted from the actual world, where people never confront problems of memory, responsibility and remorse as pure philosophical issues. They confront them while at the same time struggling to cope with the everyday: buying the bread for tomorrow's breakfast, listening to the distracting bass notes of music from a neighbour's party, worrying about the quarrel they have just had with their parents or their children. The power of creative writing is its ability to put the philosopher's big questions back into the midst of the tangle of everyday life.

And it is in that tangle itself that Johanna at Daybreak finds some kind of resolution. Memory is painful; forgiveness does not come cheaply, and may not come at all. The only path to accepting responsibility is the step-by-step path through the infinitely complex everyday world of human existence:

Side by side—our hands still touching — we went into the house, to be greeted by the fumes from a pan of milk which someone had let boil over and by the pervasive bickering of children. Enveloped in that orchestra of inveterate sounds and smells, I realised that I was back on the painful course I could never finally escape from-itself my one escape from the despotism of the past (Hutchinson 1969: 314).

\section{Retrieving lost lives}

It seems light years from the dark postwar Europe of R.C. Hutchinson's Johanna at Daybreak to the languid evenings of Brij Lal's Mr Tulsis Store: a work of history and imagination, prose and poetry set in Fiji, which was sometimes referred to by Indian migrants and those left behind as 'the Ramnik Dvip, the colorful islands or the islands of paradise' (Lal 2001: 27). As he traces the lives of the Indian indentured labourers of Fiji, their descendants, and their distant relatives in India and its diaspora, Lal always keeps a light touch. Recalling a favourite phrase of the late geographer Oskar Spate-'one does not have to be solemn to be serious' (Lal 2001: x) - he conjours up the characters of his own Fijian childhood and early adulthood with an observant eye and a wry sense of humour: the grasping storekeeper Mr Tulsi, 'his ample stomach parked 
comfortably on his knees'; Mr Tom the overseer, barking out orders in 'broken CSR Hindustani' (Lal 2001: 49, 54). The Indo-Fijian landscape evoked his words is a changing, vanishing world laden with longing:

I miss them, as I miss the touch of smell and sound,

The pungency of cane fires, embers reddening the ground,

The feel of warm rain on grass fresh mown,

Swimming in swollen rivers, menacing, brown (Lal 2001: 208).

Hutchinson was a novelist using his craft to probe deep questions of history and philosophy. Lal is an historian adopting the skills of the creative writer to break out of the straightjacket of academic prose. If Hutchinson is adventurous in his choice of themes, Lal is adventurous in his use of the written form. Mr Tulsis Store and his other 'factional' writings (as he calls them) freely combine personal reminiscences, short stories and poetry into a web of language that brings a vanished past back to life in all its complexity and sensuality. Brij Lal's journey through time is a circuitous one, building up layers of history one on another. It takes us through the dusty village streets and cane fields of Tabia, his Fijian childhood home, back to the Indian villages that were the starting point of the girmitiya (indentured labourer) diaspora, and forward to the diaspora's multiple stopping places, in Trinidad, Guyana and Surinam, even Honolulu and Canberra. There are, it seems, no permanent end points, only way stations on an endless voyage.

There are also no simple morals or conclusions, though the journey is full of suggestions about the meanings of the past. Education, books and the power of words figure prominently in the itinerary. For the children and grandchildren of the girmitiyas, education was a means to liberation from the weight of the history of indenture, and books were the windows through which their minds escaped into new and bigger worlds: "The same texts which taught us to obey the laws also taught us read books, to cherish the pleasures of the imagination. Nothing is more dangerous to the established order than an unfettered mind' (Lal 2001: 20). That faith in the power of words and imagination to change the world is sustained and grows through Lal's account of English literature classes at school, and of that great social experiment, the University of the South Pacific, where he studied in the early 1970s. The same theme reappears, too, in his account of his travels around the Fijian Islands in 1995, collecting submissions for a new Fijian constitution, of which he was to be one of the authors. With the enthusiasm of a connoisseur, Lal records, not just the multitude 
of political suggestions presented to the constitutional commission by people from all walks of life, but also the language and the metaphors in which people expressed their dreams for the future of their country. In the multitude of submissions, Fiji appears as a house, a mother, a human body, a flower garden, a loaf of bread that just needs a little yeast.

This is a deeply nostalgic journey, but not a sentimental one. Mr Tulsi's Store charts the vast changes that have overwhelmed Indo-Fijian society. It brings back to life, through words and imagination, the vanished girmitiya village with its mango trees and thatched-roof houses, its endless cycle of religious rituals, its huddles of old men seated on the verandah of the village store, playing games of riddles and telling stories about the motherland. But this is no idyllic past. The world that Brij Lal evokes is a harsh and sometimes an unforgiving one. Its people struggle with poverty, insecurity and the loneliness of separation-separation from the India they have left behind, and from the mobile younger generation, who move on and away in search of better lives. The power of tradition and of old beliefs can be sustaining, but it can also feed superstition and exploitation, or constrain and ultimately destroy lives. It cages the dreams and imaginations of women and divides Hindus from Muslims, and Indians from Fijians. The pain beneath the humour and nostalgia is nowhere more evident than in the chapter of $M r$ Tulsis Store just titled 'Ben', where Lal recalls the life and death of his eldest brother, who stayed at home and worked, in part so that his younger siblings could have the education and possibilities that he would never enjoy.

All the writings in $M r$ Tulsis Store are infused with the feeling that the author experiences in his own encounters with India: 'a vague sense of loss' (Lal 2001: 34). The loss of which they speak is not only the vanishing of an Indo-Fijian village world; it is also the loss of the dreams of a multiracial Fijian democracy: 'the Fijian turmoil has traumatised the spirit that informed our idealism and our unbounded youthful optimism about the possibilities of unlimited progressive change. So much potential, so little of it realised' (Lal 2001: 103). Expelled from Fiji by the Bainimarama government in 2010, Brij Lal remains an exile from the land of his birth, and the last chapter of Mr Tulsis Store is a poem of farewell.

'I will not let anyone forget': the words spoken by R.C. Hutchinson's Albrecht came to my mind when I read Mr Tulsis Store. In the mouth of Albrecht, they are the angry cry of the righteous. But Brij Lal's writings fight a war against forgetting in a quieter and more peaceable way. 
He insists that we remember, not just the grand tales of the tides of history and the rise and fall of empires, but also the irreplaceable small pasts of the individuals caught up in history's flows and vortices. He makes each of those small lives, and the landscape in which they were lived, matter to his readers. And that, in a way, is what history is all about: the reality of those millions of human lives that have gone before ours. The infinite complexity of each of those lives, with its pains and hopes and loves and visions of possibility. History can only rescue small fragments of a tiny fraction of those lives from the abyss of oblivion; but every fragment rescued adds to our understanding of what it is to be human.

Brij Lal's work is also, as he puts it, a 'small act of rebellion' against the academic enthusiasm for 'word games and jargon-laden, obscurantist prose, the converted talking to the converted, pandering to the educational establishment's demand for narrowly defined, peer-reviewed research, publishing to get ahead, or get funded, not necessarily read' (Lal 2001: xi).

It is, indeed, rather revolutionary in the challenges it poses to our assumptions about 'writing history'. History, as Brij Lal shows, may be written as poetry (as of course it was for many centuries in the past). It can be written as short stories in which the remembered and the recorded past is mixed in complex ways with imaginative re-creation. What matters is that its creative power should make the past come to life for readers in a very different time and place. Like the very different fictional writings of R.C. Hutchinson, Brij Lal's 'factional' writings place the big philosophical questions of history back into the endlessly complex tangle of life in which they are always played out: the world, not just of the mind, but also of the emotions and of all the physical senses.

\section{Returning to the magic mountain}

We live in a time when education and media are changing with dizzying speed. Twenty years from now, I am sure, universities will have changed beyond recognition, for better or worse. But as academics we seem oddly trapped in routine patterns of communication: the 80,000-word academic book, complete with copious footnotes; the peer-reviewed journal article; the 20-minute conference presentation in panels that never leave enough time for questions and answers. Are we unable to communicate in other ways, or only afraid of trying? 
Brij Lal's evocations of the past through essay, 'faction' and poetry point a way out of timorous straightjackets of scholarly communication; and his experiments in creative writing are interestingly paralleled by the work of another scholar who (like Brij Lal) has deeply influenced my work and life. Kang Sang-jung is a Zainichi Korean scholar of political science: Zainichi (literally, 'living in Japan') being the word commonly used to describe colonial-era migrants to Japan and their descendants. Of the same generation as Brij Lal, Kang is, like Lal, a child of the diaspora. In the 1990s he became well-known for his writings and public commentary on postcolonial themes, including his critique of orientalism in Japan's cultural images of his Asian neighbours (Kang 1996). But more recently, Kang Sang-jung, like Brij Lal, has turned increasingly to creative writing-novels or combinations of essay and fiction-to convey his ideas to an audience that extends beyond the walls of academia.

In Omoni (Mother), published in 2010, Kang moves almost imperceptibly from one form of storytelling to another. The book begins with Kang's reminiscences of his mother, U Sun-nam, and his account of her early life in the far south of Korea and journey to Japan as a 16-year-old bride. But as we follow her journey through the firestorms of the wartime bombing of Nagoya and the death of her first infant son, Haruo, we gradually start to see the world through U Sun-nam's own eyes. The book transforms itself from biography into novel:

In late autumn the days retreated swiftly, and a chill air drifted through the neighbourhood. As the sun set behind Bannichi Mountain, the 'dong, dong' of a bell sounded from somewhere in the distance. Every time that sound reached her ears, the memory of her lost son Haruo returned, and Mother gently rubbed her swollen stomach, the sign of impending birth. 'It's like Haruo is being born again. Bet this one'll be a boy. Sure to be' (Kang 2010: 101).

Omoni, like Brij Lal's Mr Tulsi's Store, evokes the harsh realities of a migrant community whose world seems utterly remote from those of the book's contemporary readers; the creative language of the novel takes over from conventional academic prose because it has the capacity to bring that world to life on the page. Just as Mr Tulsi's Store rescues the ordinary but extraordinary lives of Tabia and its inhabitants from oblivion, Omoni rescues lives of a group of first-generation Korean migrants to Japan. 
In the books that have followed, Kang has experimented with novel writing, not only as a way of reaching back into his own past, but also to convey ideas about society and history to readers who would be unlikely ever to pick up an academic work of postcolonial thought or political theory. These books reflect Kang's growing fascination with the work of Japan's most famous modern novellist, Natsume Soseki. Soseki is often seen as a quintessentially Japanese novelist whose work (in the words of one scholar) was shaped not just by western literary aesthetics but also by 'that ancient Eastern philosophy of resignation which some have described as the heart of traditional Japanese spirituality' (Odin 2001: 215). But Kang suggests that Soseki's novels can be re-read as deeply ironical and critical commentaries on society: commentaries full of relevance to the twenty-first-century world.

Kang's 2013 novel Kokoro borrows its title and elements of its structure from Natsume Soseki's most famous book. The Japanese word kokoro is not easy to translate into English because (as the nineteenth-century Japanophile Lafcadio Hearn observed) it elides into a single word the notions of heart and also of 'mind, in the emotional sense; spirit; courage; resolve; sentiment; affection; and inner meaning, just as we say in English, "the heart of things" (Hearn 1896: front matter). Soseki's Kokoro (first published in 1914) is an exploration of the human psyche in the form of two first-person narratives written from the perspective of each of the novel's unnamed main characters. The first narrative is told from the perspective of a drifting, lonely young student, who becomes for a while the disciple of an older man he meets by chance on a visit to the seaside. The second narrative takes the form of a letter written by the older manknown only as 'Teacher' (Sensei). Here the relationship is inverted, as the older man confesses to the younger the fatal error that will consume his own life: for Sensei's letter to his student is also an extended suicide note.

Kang Sang-jung's Kokoro gives the dual first-person narrative a contemporary and slightly irreverent twist by turning it into an email correspondance between a student and the author, in his role as Sensei. A core theme of Natsume Soseki's novels is the anomie and isolation of ordinary people caught up in a world that was changing with bewildering speed. Kang takes Soseki's ideas as a starting point for exploring the equally profound confusion and loneliness that many people in Japan today experience, above all in the wake of the triple disaster: 
the earthquake, tsunami and nuclear meltdown of 11 March 2011. In its final pages, the novel also becomes a moving reflection on its author's own loss: the death of his son.

In Kokoro no Chikara (The Power of Kokoro), published in 2014, Kang returns to the theme of human anxiety in a turbulently changing world. Like Mr Tulsis Store, Kokoro no Chikara is an adventurous mixture of literary forms. It consists of a series of essays, interleaved with chapters of a short novel. Both the essays and the novel take us back again to Natsume Soseki's classic. They also evoke another great modern novel that was being written as Soseki wrote Kokoro, though it would be published 10 years later: Thomas Mann's The Magic Mountain (Der Zauberberg). Set in a tuberculosis sanatorium in the Swiss mountains above Davos, Mann's novel, like Soseki's, follows the meandering fate of an individual adrift on the currents of modernity. Mann's main character Hans Castorp, during his seven years in the sanatorium, encounters and struggles with most of the philosophies and ideologies of modern Europe. But The Magic Mountain ends with its moral dilemmas unresolved and its main character still drifting and uncommitted. Castorp leaves the sanatorium only to confront the horrors of World War I on the battlefields of the Western Front.

The unconventional novel contained in Kang Sang-jung's Kokoro no Chikara brings Soseki and Mann together across time and continents. As General MacArthur's occupation forces take control of a defeated and war-devastated Japan in 1945, a multinational collection of peoplediplomats from Japan's wartime allies, Germany and Italy, politicians from the vanished state of Manchukuo and others-gather in the limbo of an old hotel in the Japanese mountain resort of Hakone, waiting for their fates to be decided. Among them are two men: Hans Castorp, who has survived World War I to become the representative of his family's trading company in Japan; and Kawade Ikurō, the 'student' from Soseki's novel Kokoro, who has lived in Germany and become a translator working for the Japanese Foreign Service. In the rarified world of the post-defeat Hakone hotel-a world not unlike that of Mann's sanatorium-the two characters strike up a friendship, and the narratives of The Magic Mountain and Kokoro flow into one.

Through the characters of Castorp and Kawade, and their conversations in the mountains of Japan, Kang explores the themes of the passage of time and the search for meaning in a world ruled by the remorseless laws 
of the competitive economy. He contrasts the dreamlike Davos of Thomas Mann's magic mountain with the Davos that we know today: that gaudy stage where the World Economic Forum performs its annual rituals. Universities, he argues, have become too much like the second Davos, and not enough like the first. We need more magic mountains-more spaces where time slows down and there is scope for reflection and conversation, unpressured by the demands of global economic competition (Kang 2014: 106-14).

For Kang, the appeal of the characters of Castorp and Kawade lies in the fact that their discussions and self-doubts do not lead to any grand conclusions. They are outsiders, never quite in tune with the age in which they live. But their unease and their restless search for something better does not end with the drum-rolls and clashing cymbals of ideological certainties or revolutionary deeds. Kokoro no Chikara ends in the 1960s, with Japan and Germany rapidly recovering from the scars of war, and equally rapidly forgetting the lessons of defeat. Kawade, the 'student' of Natsume Soseki's novel Kokoro, is now on the brink of old age, and finds himself at odds with a society in which the pursuit of wealth and power threatens to sweep away the memories of the past. His teacher's suicide, he realises, was itself precisely an act of rebellion against 'an age in which everything was reduced to money, an age when friendship was betrayed and even blood bonds were sundered, an age when people fell into utter loneliness, an age filled with desire and ostentation' (Kang 2014: 185).

The real strength of the heart, though, lies not in acts of rebellion like Sensei's suicide, but rather in the act of survival: going on living, while remaining at odds with the spirit of the age you live in. Like Johanna Schechter, Kawade finds himself back on the 'painful course he could never finally escape from', the path of day-to-day survival in an unforgiving world.

\section{Stories without end}

Creative writing shakes up our senses and questions our certainties. R.C. Hutchinson makes his readers share the experience of Johanna Schechter's amnesia, and so become more conscious of the amnesia in their own lives. Kang Sang-jung prompts us to imagine what happens to literary characters after the last page of the novel, intertwining their lives with ours. Brij Lal enriches our visions of the forms in which history can be 
passed on from one generation to another, challenging us to tell and write our histories in new ways. These works-blurring the boundary between fact and fiction, history and literature-are deeply disconcerting to the conventional academic view of the world. They bring direct and sometimes raw emotions into a space usually ruled by the abstract intellect. They make history and social thought personal, breaking down the barriers that shield the life of the mind from simple, total life.

Because they are unfamiliar and unsettling, it is easy to marginalise them. Hutchinson's novels have remained 'great forgotten works' partly because they failed to fit comfortably into the accepted literary conventions of his day. Brij Lal's and Kang Sang-jung's excursions into the realms of fiction and 'faction' are almost certainly seen by some academics as peripheral, distractions from the real work of the scholar. But the challenge of these writings goes to the core of scholarship. Why, and for whom, do we read, research and write? How do we communicate ideas, and to what audience? How can we share, not only ideas, but also the passion and imagination to expand and live those ideas? How can we make our words alive and dangerous, so that they go on creating small new worlds in many minds, long after our readers have reached the last full stop (or the last question mark) on the final page?

\section{References}

Caché. 2005. Dir. Michael Hanneke, prod. Margaret Ménégoz and Veit Heiduschka, starring Daniel Auteuil, Juliette Binoche and Maurice Bénichou.

Derrida, Jacques. 2001. On Cosmopolitanism and Forgiveness, trans. Mark Dooley and Michael Hughes. London: Routledge.

Green, Robert. 1985. R.C. Hutchinson: The Man and his Books. Metuchen,

$\mathrm{NJ}$ and London: Scarecrow Press.

Hutchinson, R.C. 1969. Johanna at Daybreak. New York and Evanston: Harper and Row, 1969.

Kang Sang-jung. 1996. Orientarizumu no Kanata e: Kindai Bunka Hihan. Tokyo: Iwanami Shoten.

—_. 2010. Omoni. Tokyo: Shueisha. 
—. 2013. Kokoro. Tokyo: Shueisha.

- 2014. Kokoro no Chikara. Tokyo: Shueisha.

Lal, Brij V. 2001. Mr Tulsis Store: A Fijian Journey. Canberra: Pandanus Books.

McGonegal, Julie. 2009. Imagining Justice: The Politics of Postcolonial Forgiveness and Reconciliation. Montreal and Kingston: McGillQueen's University Press.

Odin, Steve. 2001. Artistic Detachment in Japan and the West: Psychic Distance in Comparative Aesthetics. Honolulu: University of Hawai'i Press.

'Peter Hobbs hails R.C. Hutchinson and his "brave, compassionate, moral" novel "A Child Possessed". Faber and Faber, 22 April 2013. Online: faberfindsblog.co.uk/peter-hobbs-hails-r-c-hutchinson-and-his-bravecompassionate-moral-novel-a-child-possessed/ (accessed 17 November 2016). 
This text is taken from Bearing Witness: Essays in honour of Brij V. Lal, edited by Doug Munro and Jack Corbett, published 2017 by ANU Press, The Australian National University, Canberra, Australia. 